\title{
Purism About Educational Justice
}

\author{
Ben Kotzee \\ University of Birmingham
}

In his paper, "What is the Meaning of Educational Injustice" Alex Nikolaidis investigates what it means to call an educational arrangement just or unjust. He outlines a number of forms of educational injustice that have been discussed in the literature; for instance: distributive, cultural, political, epistemic, formative, retributive and restorative forms of injustices pertaining to education have all been discussed in the literature.

At first glance, the list is a rag bag. They comprise very different kinds of wrongs-for instance, distributive injustice is clearly a material wrong and cultural injustice a more intangible or symbolic wrong-and, in Section II, Nikolaidis draws attention to the problem created by the fact that there are so many different concepts of educational injustice: that it is hard to know which kind of injustice to act on (or act on first). One might also add that, with so many different kinds of injustice in education, it is hard to know who must act: teachers and schools, parents, educational policy makers, employers . . . who? Different groups of people are potentially to blame for different kinds of educational injustice and different groups are able or unable to correct them and, thus, what kinds of injustice one focuses on also shifts the burden for ameliorating injustice onto different people. Nikolaidis' paper is essentially an attempt to outline one essential form of educational justice that philosophers can use to evaluate whether a form of injustice is indeed "educational" and that policy makers and practitioners can use to decide which injustices to tackle most proactively. 
Drawing on a proposal by Thompson, Nikolaidis distinguishes between the different kinds of concepts one uses to think about injustice. For instance, the distribution of funding or resources like personnel, buildings, equipment, and the like. is not a particularly educational concern. Injustice in the distribution of funding or resources is a problem that afflicts many different kinds of public service, not just education; and thinking about the distribution of funding or resources is common across a number of academic disciplines interested in public policy and management. However, concepts like "students as knowers" or "formation" are at the heart of the study of education and belong naturally in the field, discipline or subject called "Education." Simply put: Nikolaidis thinks that education scholars should study educational matters, using educational concepts; ergo, when studying justice, education scholars should study it "educationally."

From amongst the list of educational injustices discussed above, Nikolaidis thinks that the two kinds of injustice that are purely educational are epistemic injustice (because it has to do with the content of education) and formative injustice (because it has to do with education's formative end-goal of shaping children's character positively) and, in Section IV, he offers an account that synthesizes these two concerns. He holds that one's epistemic capacities influences one's potential to form one's life in a certain way. Increased knowledge and understanding of the world improve one's intellectual exploration and decision-making capacity and thereby offer more possibilities for one to explore regarding how one's life may develop, as well as more intellectual means to realize those possibilities. One's formative status also influences one's epistemic standing. If one is capable of forming a flourishing life of one's own, that includes the opportunity to become a better knower. Following Christopher Martin, Nikolaidis calls this hybrid category "formative epistemic justice." He holds that the 
proper category of educational justice and injustice that philosophers of education should be interested in is "formative epistemic justice"fairness in the intellectually formative potential that education provides to children.

Nikolaidis' unpacking of the many different kinds of educational injustice-and his focus on the difference between the logic of educational justice and the logic of social justice-is salutary. However, in how it sets up the difference between what is "educational" and what is "non-educational," the paper relies on another distinction-between the instrumental/intrinsic value of education-that isn't acknowledged head on. Nikolaidis makes much of the distinction between educational and non-educational concepts; however, when he explains what concepts are "educational" and what concepts are "non-educational," he falls back on equating non-educational and instrumental value and on equating educational and intrinsic value. When seen in these terms, the distinction between how the field of Education should study injustice and how it is studied in other academic disciplines (like Public Policy or Public Management) becomes a red herring. After all, who is to say what discipline can or should use what concepts? Many different disciplines use the same concepts; for instance, all of the Social Sciences use broad concepts like "class," "market," "society," and the like. They do not "belong" to one field but not to another. Rather, the educational/non-educational distinction is just the instrumental/non-instrumental distinction in disguise and it is that distinction that is still the most important to focus on.

To my mind, the interesting thing about justice as it pertains to education is that what we mean by "justice" in education can have two such varying meanings: justice in the sense of evaluating fairly what students have learned or not learned and justice in the sense of 
social action to provide or withhold access to an educational goods. Educational institutions like schools and universities have internal rules for how educational goods are distributed; for instance, schools and universities reserve the highest learning opportunities (say, being enrolled in a high school course in calculus) only for those students who are qualified for those opportunities on the basis of successful prior study (for instance, first passing high school algebra). This is not merely a case of "rationing" it is a case of "qualification." It is part of the logic of education that educators will only teach something to students that the students are qualified to master or understand based on prior knowledge. In a sense, the selection of students for learning opportunities (or learning opportunities for students, it comes to the same thing) will always be "discriminatory," in the sense of making distinctions between students and not necessarily in the sense of doing them an injustice. While schools and universities are generally trusted to make their own rules about qualifications, they also play an important role in society and sometimes social demands (for instance preparing children for work, rectifying past injustices, and the like) demand that the school or university bend its own internal rules or logic to the service of societal ends. For instance, in the name of rectifying past injustice, schools may be asked to change their selection policies for important classes (like calculus). In schools and universities what we might call justice in the "educational" sense is regularly in conflict with justice in the broader "social" sense.

Can we think of other examples of an institution that has an internal logic, but plays a social role and therefore faces social demands that might conflict with that internal logic? It is not hard to find examples in the fields of, for instance, sports or the arts. Some artists are adamant that art should operate only according to its own rules and that artistic merit should never be compromised in service of social goals; 
some other artists are more than happy to place art in the service of society. The same goes with sports. Applying Nikolaidis' reasoning, we can readily see that in fields like art or sports, just as in education, there is plausibly a difference between "artistic justice" or "sporting justice" and "social justice."

In the end, Nikolaidis helps us to identify a general problem that affects rule-bound institutions that play an important social role: institutions might have their own internal standards of justice that can come into conflict with broader social justice goals. "Purists" might insist that their institution's standards are internal to or specific to their own field and that those standards should have primacy over more general standards of social justice within the institution; by contrast, "social-ists" might insist that standards of justice are general across all social institutions and that general social justice standards trump more field-specific standards. (We might also call "purists" "internalists" and "social-ists" "externalists.") The question is when a social institution's own pure, internal standards of justice are so special or important that they should not be bent in the service of some greater social goal. What kinds of outcomes might arise from prioritising either educational or social justice when the two kinds of standards compete? I can see three different possible outcomes:

1. Different standards, same outcomes: Perhaps, education is of such basic and universal benefit to society that leaving the education system to operate according to its own standards of justice will actually always benefit society, if not in the short run, then at least in the long run. While the logics of educational justice and social justice are different, we may find that applying educational standards of justice will ultimately produce social justice as a longterm by-product.

2. Educational justice re-thinks social justice: Alternatively, one might find that considering educational justice in its 
own terms forces us to re-think our conception of social justice. If one could show that some situation that appears socially unjust is educationally quite just, this might cause one to re-think whether one should not perhaps allow that state of affairs to persist more generally, as it is, after all, not as unfair as it might at first glance appear. On this view, one should pay attention to educational justice (in its own terms) for the lessons it may yield regarding social justice.

3. Social justice re-thinks educational justice: Of course, if it is possible (option 2) that proper consideration of educational justice might convince us that our standards of social justice are wrong, then the opposite must be possible too. It might be possible that proper consideration of social justice might convince us that what we previously thought to be educationally just, is actually not only socially, but also educationally unjust.

Being, like Nikolaidis, a purist, I have high hopes regarding possibilities 1 and 2. While much more philosophical work is needed to sharpen the purist case, I am grateful to Nikolaidis for sketching out the terrain so clearly. I hope he does not mind my attaching the name of "purism" to his conception of an intrinsically educational meaning of "justice." 